\title{
Seasonal and interannual patterns of intertidal microphytobenthos in combination with laboratory and areal production estimates
}

\author{
Shigeru Montani ${ }^{1, *}$, Paolo Magni ${ }^{2}$, Nao Abe $^{3}$ \\ ${ }^{1}$ Graduate School of Fisheries Sciences, Hokkaido University, Minato 3-1-1, Hakodate 040-8611, Japan \\ ${ }^{2}$ IMC International Marine Centre, Località Sa Mardini, 09072 Torregrande-Oristano, Italy \\ ${ }^{3}$ Department of Life Sciences, Kagawa University, Miki Kagawa 761-0795, Japan
}

\begin{abstract}
From April 1994 to December 1997, we studied the microphytobenthic assemblages in surface $(0$ to $0.5 \mathrm{~cm})$ and subsurface $(0.5$ to $2 \mathrm{~cm})$ sediments at spring low tide along a transect of 5 stations in an estuarine sandflat of the Seto Inland Sea, Japan. At the innermost sampling station, microphytobenthos biomass (chl a) was also investigated in a vertical profile to $10 \mathrm{~cm}$ depth from December 1994 to April 1996. The chl a contents at the 2 uppermost layers were well correlated with each other, with a mean decrease of $34 \%$ from the surface to subsurface layer. Chl a tended to decrease rapidly through the vertical profile and was reduced to $3.2 \pm 1.4 \% \mathrm{SD}$ in the 9 to $10 \mathrm{~cm}$ layer. There was a progressive decrease in the chl a content every year in fall and the occurrence of major peaks in early spring and/or summer. This was accompanied by a significant increase in microphytobenthos biomass from 1994 to 1995 and from 1995 to both 1996 and 1997. The microphytobenthos biomass in surface sediments (mean of 5 stations) ranged between 27.7 (October 1994) and $120 \mathrm{mg} \mathrm{chl} \mathrm{a} \mathrm{m}^{-2}$ (July 1997), or between 3.9

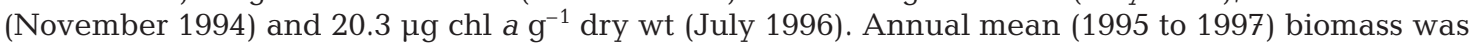
$72.3 \pm 27.1 \mathrm{mg} \mathrm{chl} \mathrm{a} \mathrm{m}^{-2}$ and $11.0 \pm 4.3 \mu \mathrm{g} \mathrm{chl} \mathrm{a} \mathrm{g}{ }^{-1} \mathrm{dry}$ wt. These values rank in the mid-upper range of microphytobenthic biomass for intertidal sediments. In addition to the field investigations, we conducted laboratory experiments on a dominant diatom species, Navicula sp. The photosynthetic rate of Navicula sp. was saturated at a light intensity of $165 \mu \mathrm{E} \mathrm{m}^{-2} \mathrm{~s}^{-1}$ at $21^{\circ} \mathrm{C}$. No photoinibition was found at higher light intensities up to $400 \mu \mathrm{E} \mathrm{m}^{-2} \mathrm{~s}^{-1}$. The relationship between temperature and photosynthetic rate was positive and linear within a temperature range between 10 and $35^{\circ} \mathrm{C}$ at $55 \mu \mathrm{E} \mathrm{m}{ }^{-2} \mathrm{~s}^{-1}$. Areal 'potential' primary production of microphytobenthos was between 0.32 (December 1994) and $3.0 \mathrm{~g} \mathrm{C} \mathrm{m}^{-2} \mathrm{~d}^{-1}$ (July 1997), with an annual mean of $1.2 \mathrm{~g} \mathrm{C} \mathrm{m}^{-2} \mathrm{~d}^{-1}$. Uni- (summer) or bi-modal (spring and summer) peaks of microphytobenthos biomass and primary production highlighted a marked interannual variability. Marked seasonal patterns were also recognizable, with primary production of microphytobenthos significantly higher both in spring and summer than in winter and fall.
\end{abstract}

KEY WORDS: Microphytobenthos · Biomass $\cdot$ Chl a $\cdot$ Navicula sp. P Primary production · Seasonality · Interannual variability $\cdot$ Tidal flat $\cdot$ Seto Inland Sea

\section{INTRODUCTION}

During the last decade, major interest has arisen on the role of intertidal microphytobenthos as a primary carbon source for estuarine food webs and as an important component in the cycling of nutrients in tidal estuaries (Sullivan \& Moncreiff 1990, Heip et al. 1995, MacIntyre et al. 1996, Guarini et al. 1998, Middelburg et al. 2000).

*Email: montani@fish.hokudai.ac.jp
Due to the high variability of benthic microalgae distribution in these ecosystems (Colijn \& De Jonge 1984, Lukatelick \& McComb 1986, Delgado 1989, Burford et al. 1994, Guarini et al. 1998), it is important that studies on the occurrence and development of microphytobenthic assemblages should be based on detailed and/or extended field observations, also depending on the temporal scale to be investigated. Several reports have focused on the short-term (hours, days) variability of 
microphytobenthos biomass and primary production in relation to their rhythmic vertical migration (Pinckney \& Zingmark 1991, Barranguet et al. 1998, Kromkamp et al. 1998), influenced by tidal and light cycles (Pinckney \& Zingmark 1991, Dring \& Lüning 1994, Smith \& Underwood 1998), and tidal currents and waves (Stevenson 1983, Kingston 1999). On a longer term, earlier studies suggested that the annual primary production of intertidal microphytobenthos can be estimated on the basis of relatively few chl a samples distributed over the year (Cadée \& Hegeman 1977, Colijn \& De Jonge 1984). Colijn \& De Jonge (1984) however acknowledged that this method only yields a limited insight into the year-round variability of the primaryproduced carbon available for estuarine processes (e.g. grazing, burial). More recently, simulation models have been used to calculate the annual primary production of intertidal microphytobenthos based on either monthly (Cammen 1991, Pinkney \& Zingmark 1993) or shorter (fortnightly and daily, Serôdio \& Catarino 2000) timescale measurements. However, field observations on a longer (interannual) scale are very limited (Cadée \& Hegeman 1974, Riaux-Gobin 1985, Peletier 1996). Little information is thus available on the extent of seasonal and interannual fluctuations of intertidal microphytobenthos biomass and primary production in these highly variable ecosystems.

This work is part of a long-term multidisciplinary project which aims to quantify the cycling of biophilic elements $(C, N, P, S i)$ in a tidal estuary of the Seto Inland Sea, Japan, and to assess the role of primary producers (microphytobenthos) and consumers (macrofauna) in this cycling. As an initial phase of this project, we evaluated the short-term $(24 \mathrm{~h})$ and seasonal (2 yr) variability of the water chemistry along the estuary (Montani et al. 1998, Magni \& Montani 2000, Magni et al. 2002). In parallel, we investigated the spatial/temporal distribution of macrofaunal communities on the intertidal and the subtidal zones of this estuary (Magni 1998, Magni \& Montani 1998) and quantified their contribution on the processes of nutrient regeneration within the estuary (Magni et al. $2000 \mathrm{~b})$. The present study is an extension of a biweekly survey which lasted 13 mo (July 1993 to July 1994) and was carried out on the same flat, and investigated the development of microphytobenthic assemblages at an upper and a lower intertidal station differing in elevation and grain-size composition (Magni \& Montani 1997). Here, we will focus on the seasonal and interannual variability of microphytobenthic assemblages in the lower part of the intertidal zone based on extended field observations over a 4 yr period. Additionally, in the laboratory we conducted incubation experiments on the photosynthetic rates of a dominant microphytobenthic species (Navicula sp.) collected from the study area. Using an indirect approach, we will apply these rates to the microphytobenthic biomass found in the field and photosynthetically competent to evaluate the seasonal and/or interannual patterns of both biomass and primary production of microphytobenthos over a period spanning from April 1994 to December 1997.

\section{MATERIALS AND METHODS}

Field surveys. Study area and sampling procedure: We carried out the field investigations on an intertidal flat in the Seto Inland Sea, SW Japan (Fig. 1). The flat is located in a mixed-semidiurnal type estuary with a mean tidal range of ca. 2 m (Montani et al. 1998, Magni et al. 2002). Complete emersion of the sampling site occurs twice a month during a spring low tide at ca. $+50 \mathrm{~cm}$ the local (Takamatsu Port) mean sea level (Magni \& Montani 1998). We fixed a transect line of 5 stations (Stns B1 to B5) set at $25 \mathrm{~m}$ regular interval (slope of ca. $30 \mathrm{~cm}$ toward the seashore) between the LWL (low water level) and the ELWL (extreme low water level) (Fig. 1). The sediments are sandy and relatively homogeneous with a mud fraction $(<0.063 \mathrm{~mm})$ comprising $<3 \%$ of the total weight. Sampling activities were always conducted during a spring low tide of every month to ensure protocol uniformity throughout the 4 yr study period and to minimize within-day variability in the distribution of microphytobenthos (Pinckney \& Zingmark 1991, Barranguet et al. 1998, Kromkamp et al. 1998). On each sampling occasion, we randomly collected sediment samples at 7 to 8 locations of each station using an acrylic core tube $(3 \mathrm{~cm}$ in diameter) which was gently pushed by hand into the sediment. The sediment was carefully extruded and the surface $(0$ to $0.5 \mathrm{~cm})$ and subsurface $(0.5$ to $2 \mathrm{~cm})$ layers sliced off. Sediment samples from the same layer were pooled and brought to the laboratory within $2 \mathrm{~h}$ for further treatment and analysis. Additionally, at Stn B5, we collected sediment samples through the sediment column (surface: 0 to 0.5 ; subsurface: 0.5 to $2 \mathrm{~cm}$; and each following $\mathrm{cm}$ to $10 \mathrm{~cm}$ depth).

During sampling activities, we also monitored salinity, temperature and dissolved oxygen (DO) concentration of ebbing water at a shallow creek (20 to $50 \mathrm{~cm}$ in depth) formed during low tide (Stn H1, Fig. 1), where nutrients and suspended particulate matter were also investigated between 1994 and 1996 (Magni \& Montani 2000). Hydrological measurements were made using a portable salinometer (YSI model 30) and DO meter (UK 2000), respectively. Data of monthly rainfall and solar radiation were obtained from the Takamatsu Meteorological Agency Station, located near the flat under investigation. 
We conducted the field surveys on a monthly basis from April 1994 to December 1997, except in May and September 1995, when sampling occurred fortnightly (total of 47 sampling occasions). For May and September 1995, data from 2 sampling dates for each station are averaged and reported as monthly values. Measurements through the vertical profile at Stn B5 were made monthly from December 1994 to April 1996 (total of 17 sampling occasions).

Sediment treatment and analysis: In the laboratory, chlorophyll a $(\mathrm{chl} a)$ and phytopigment degradation products (i.e. total phaeopigments) were extracted from duplicate subsamples of wet sediment (ca. $1 \mathrm{~g}$ ) using $90 \%$ acetone. After $24 \mathrm{~h}$ of darkness at $4^{\circ} \mathrm{C}$, the samples were sonicated for $5 \mathrm{~min}$, centrifuged at $3000 \mathrm{rpm}$ $(1000 \times g)$ for $10 \mathrm{~min}$, and extracts were spectrophotometrically analyzed for chl $a$ and pheaopigment content. Chl $a$ and phaeopigments values were obtained before and after acidification with $1 \mathrm{~N} \mathrm{HCl}$, respectively, according to Lorenzen's (1967) method, as described in Parsons et al. (1984), where the volume of water is substituted by the dry weight (DW) of the sediment expressed in gram. Values were thus expressed, corrected for porosity as measured by the water con-

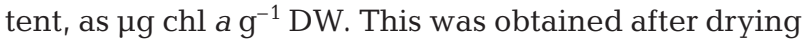
duplicate sediment subsamples (ca. $1 \mathrm{~g}$ ) at $105^{\circ} \mathrm{C}$ for $20 \mathrm{~h}$. From the same samples, we also measured the acid-volatile sulfide content and the nutrient concentrations $\left(\mathrm{NH}_{4}{ }^{+}-\mathrm{N},\left[\mathrm{NO}_{3}{ }^{-}+\mathrm{NO}_{2}{ }^{-}\right]-\mathrm{N}, \mathrm{PO}_{4}{ }^{3-}-\mathrm{P}\right.$ and $\mathrm{Si}[\mathrm{OH}]_{4}{ }^{-}$ $\mathrm{Si}$ in the porewater, for which relevant results will be reported elsewhere (P. Magni \& S. Montani unpubl.).

During the 4 yr study, a total of 470 sediment samples, including the surface and subsurface layer, were analyzed in duplicate. At Stn B5, 170 sediment samples were taken through the vertical profile.

Laboratory experiments. Microalgal isolation and growth rate: Surface sediment samples for microalgal isolation were collected at Stn B4 on 3 different occasions during our routine field survey (May 23, June 24 and July 22, 1997). In the laboratory, ca. $1 \mathrm{~g}$ of sediment sample was placed in a Petri dish along with $10 \mathrm{ml}$ of enriched medium containing $120 \mathrm{mg} \mathrm{l}^{-1}$ $\mathrm{NaNO}_{3}, 5 \mathrm{mg} \mathrm{l}^{-1} \mathrm{~K}_{2} \mathrm{HPO}_{4}$ and $33 \mathrm{mg} \mathrm{l}^{-1} \mathrm{NaSiO}_{3} 9 \mathrm{H}_{2} \mathrm{O}$. This was incubated for $3 \mathrm{~d}$ at $21^{\circ} \mathrm{C}$ with a $14: 10 \mathrm{~h}$ light:dark photoperiod at $55 \mu \mathrm{E} \mathrm{m} \mathrm{m}^{-2} \mathrm{~s}^{-1}$. Observations were made using a stereomicroscope to evaluate the composition of these benthic microalgal assemblages. On all the different occasions, an individual diatom species, Navicula sp., was found to be dominant in our study area and was subsequently selected for microalgal isolation. After $3 \mathrm{~d}$ of incubation, Navicula sp. was isolated using a modified Pasteur micropipette and transferred into a test tube (previously autoclaved at $120^{\circ} \mathrm{C}$ ). Test tubes were incubated for $2 \mathrm{wk}$ and inspected for bacterial contamination and/or the presence of different microalgal species. After which, axenic monoclonal cultures of Navicula sp. were selected. To investigate the growth rate of Navicula sp., a known volume of the monoclonal culture was added to several glass vials and incubated at $21^{\circ} \mathrm{C}$ in $5 \mathrm{ml}$ of enriched medium with a 14:10 h light:dark photoperiod at $55 \mu \mathrm{E} \mathrm{m}^{-2} \mathrm{~s}^{-1}$. Triplicate samples were filtered daily on a GF/F (Whatman) filter. Each filter

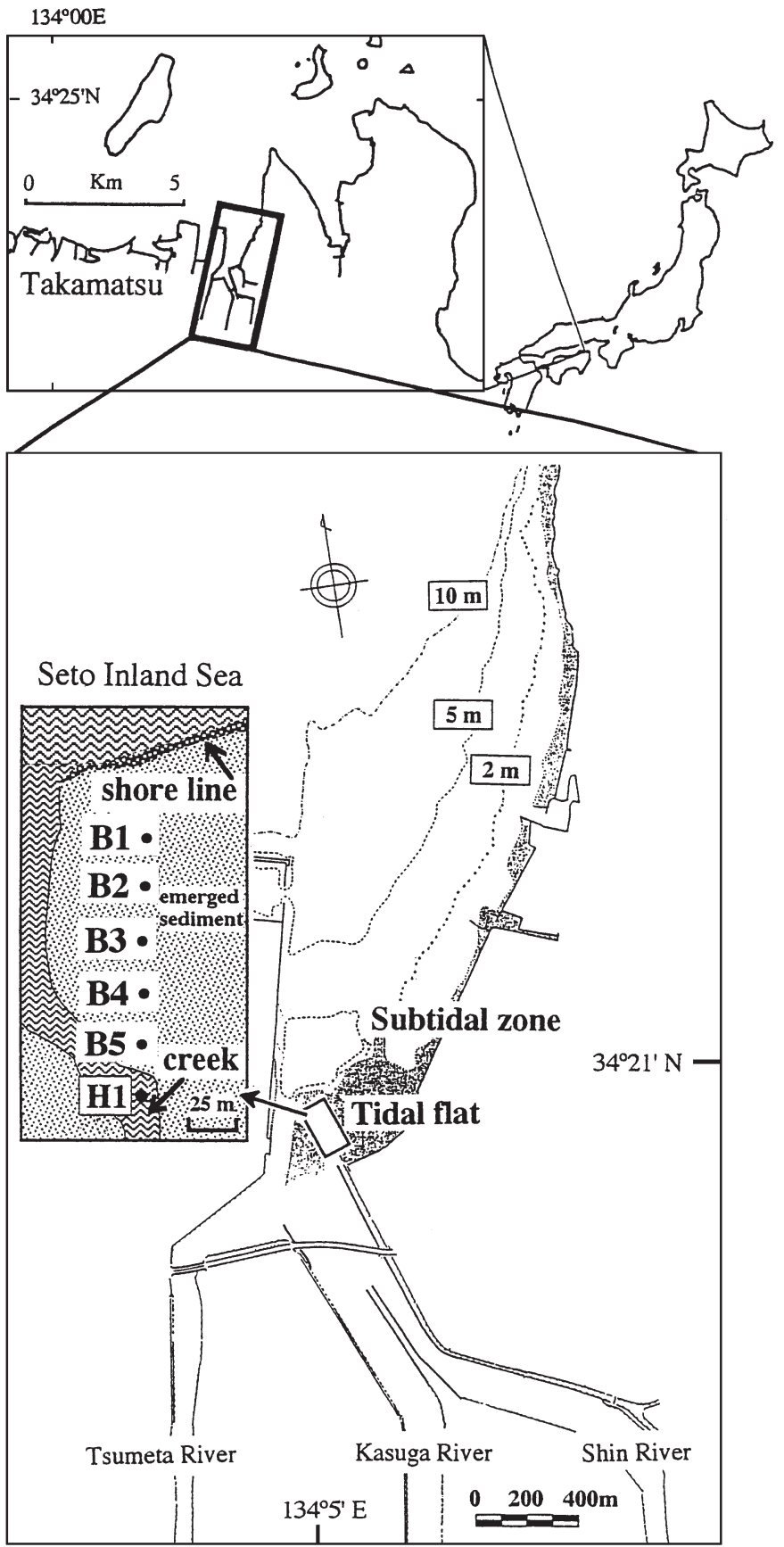

Fig. 1. Study area and location of sampling stations. Stns B1 to B5: emerged stations for sediment samples; Stn H1: sampling site of hydrological measurements in ebbing water 
placed into the original vial and the chl a content extracted by N,N-dimethylformamide (DMF) and determined as according to Lorenzen's (1967) method. The extinction coefficient was $665 \mathrm{~nm}$ and correction for turbidity was made at $750 \mathrm{~nm}$, using both DMF and acetone (field survey) as an extractant (Magni et al. 2000a).

Production rates of Navicula sp.: A volume of newly isolated Navicula sp. culture was transferred into a $100 \mathrm{ml}$ Erlenmeyer flask and incubated for $4 \mathrm{~d}$. Following this, the flask was filled with enriched medium and tightly closed with a rubber cap ensuring that no air remained. An oxygen probe (YSI model 5300) was fitted to the cap. On the internal side of the flask wall, a magnetic stirrer was provided. The flask was illuminated using a combination of artificial and microscope light (Olympus, Model LGPS). The oxygen evolution in the flask and that in an air-saturated vessel were recorded continuously for 1 to $2 \mathrm{~h}$. The flask was then covered to generate a dark condition and the oxygen evolution was again recorded continuously for 1 to $2 \mathrm{~h}$. The difference between light and dark oxygen evolution was used to calculate the production rate, after converting $\mathrm{O}_{2}$ measurements to $\mathrm{C}$ values according to Redfield et al. (1963) stoichiometric ratios. Several incubations were conducted keeping either temperature or light intensity constant. In treatments at $21^{\circ} \mathrm{C}$, 7 different light intensities were used, varying from 0.7 to $396 \mu \mathrm{E} \mathrm{m}^{-2} \mathrm{~s}^{-1}$; in treatments where light intensity was constant at $55 \mu \mathrm{E} \mathrm{m} \mathrm{m}^{-2} \mathrm{~s}^{-1}$, temperatures were 10 , $15,25,30$ and $35^{\circ} \mathrm{C}$.

Chl a content (microphytobenthos biomass) was determined at the end of the incubation. The culture was filtered on a GF/F (Whatman) filter, which was then transferred into the original flask, and $20 \mathrm{ml}$ of DMF were added for pigment extraction. Samples were at $-20^{\circ} \mathrm{C}$ until analysis, which was carried out within $10 \mathrm{~d}$. Chl a content was analyzed after centrifugation at $2000 \mathrm{rpm}(800 \times g)$ for $10 \mathrm{~min}$ according to Parsons et al. (1984).

Cell number/chl a relationship: Ten $\mathrm{ml}$ of distilled water were added into the flask which was sonicated to suspend the diatoms attached to the flask wall. The resuspension was transferred into 3 tubes which were centrifuged at $2000 \mathrm{rpm}(800 \times g)$ for $10 \mathrm{~min}$. After this, the supernatant was removed and $1 \mathrm{ml}$ of microalgae was diluted in $100 \mathrm{ml}$. Cell count was conducted in triplicate.

Elemental composition of Navicula sp.: For the determination of the elemental composition $(\mathrm{C}, \mathrm{N}, \mathrm{P}$ and $\mathrm{Si}$ ) of Navicula sp., Navicula sp. was placed on a number of pre-ignited GF/F filters and incubated in enriched medium in a Petri disk. After $4 \mathrm{~d}$ during the exponential growth phase, the filter was cut in 2 equal parts. One half of the filter was used for the chl a deter- mination (as according to Parsons et al. 1984), and the other half for the determination of elemental composition of Navicula sp. Carbon (C) and nitrogen (N) content were determined using a $\mathrm{CHN}$ analyzer (Yanako, model MT-3), and phosphorus (P) and silicon (Si) content were determined using $\mathrm{K}_{2} \mathrm{~S}_{2} \mathrm{O}_{8}$ and $\mathrm{Na}_{2} \mathrm{CO}_{3}$ digestion method, respectively (Parsons et al. 1984).

An indirect approach for areal production estimates. As an attempt to evaluate the temporal scaling and variability of areal primary production of microphytobenthos in our study area, we derived an indirect and integrated approach based on our regular and extended field measurements of microphytobenthos biomass, in combination with irradiance- and temperature-dependent production estimates of the predominant microalgal form found in the field, Navicula sp. (see above, 'Laboratory experiments').

For each month during the 4 yr of the survey, we calculated the irradiance intensity reaching the surface sediments in 3 different situations, while also taking into account the temporal variation of sediment submersion and the extent of the screening effect of the water column during daytime. The first situation was that on the sampling day, the other days were selected at 2 different tidal cycles within 1 wk before and after the sampling day. The other 2 situations were considered in relation to the tidally dependent variability of emersion/submersion period of sediments versus water column depth during daytime (e.g. complete sediment emersion occurs only during a spring tide, i.e. the sampling day). For each of the 3 situations, the daily irradiance $\left(\mathrm{MJ} \mathrm{m}^{-2} \mathrm{~d}^{-1}\right)$ intensity reaching the surface sediments, converted into $\mu \mathrm{E} \mathrm{m} \mathrm{m}^{-2} \mathrm{~s}^{-1}$ (1 MJ $\mathrm{m}^{-2} \mathrm{~d}^{-1}=4.52 \mathrm{E} \mathrm{m}^{-2} \mathrm{~d}^{-1}$ ), was calculated in 2 opposite tidal states occurring within that day: one as a daytime high-tide situation and maximum screening effect of the water column, and the second one as a daytime low-tide situation. Accordingly, the actual irradiance reaching the surface sediments was calculated using the following exponential equation:

$$
y=95.2 \times 10^{0.143 x}
$$

where $y$ is the percentage of irradiance reduction through the water column, i.e. $100 \%$ of light intensity at $0 \mathrm{~m}$ water depth during sediment emersion occurring at $+50 \mathrm{~cm}$ (Magni \& Montani 1998), and $x$ is the depth of the water column (maximum depth $2 \mathrm{~m}$, Montani et al. 1998).

The irradiance attenuation through the surface sediments was calculated by direct measurements from core samples of sediments collected at the sampling stations. To determine the coefficient of irradiance attenuation through the sediments, we used a light sensor LI-COR LI-200SA. Firstly, in the laboratory, the light sensor, which was placed beneath a cylindrical 
plate that was open in the middle, was exposed to full light passing through a wrapping film. The value recorded $\left(1249 \mu \mathrm{E} \mathrm{m} \mathrm{m}^{-2} \mathrm{~s}^{-1}\right)$ was used as $100 \%$ light penetration. Subsequently, the uppermost 2 and $5 \mathrm{~mm}$ layers of the sediments were carefully extruded, the cores sliced off and alternately placed on the wrapping film. The mean values of light intensity recorded by the sensor below the 2 and $5 \mathrm{~mm}$ slices $\left(1.3\right.$ and $0 \mu \mathrm{E} \mathrm{m} \mathrm{m}^{-2}$ $\mathrm{s}^{-1}$, respectively) were used to calculate the curve of light reduction with depth. This was described by the following exponential equation:

$$
y=100 \times 10^{-1.49 x}
$$

where $y$ is the percentage of light reduction through the sediments (i.e. $100 \%$ of light intensity at $0 \mathrm{~mm}$ depth) and $x$ is the sediment depth. This equation was used to calculate the photosynthetic active layer. Based on these calculations, light penetration exponentially decreased to ca. 77 and $97 \%$ at the 0.4 and $1 \mathrm{~mm}$ depths, respectively. Accordingly, factors of light attenuation through both the water column (i.e. $f_{\mathrm{w}}$ varying depending on the tidal state/amplitude and being maximum, $f_{\mathrm{w}}=1$, during sediment emersion) and the surface sediments (i.e. $f_{\mathrm{S}}$, being $f_{\mathrm{S}}=0.5032$ and 0.0323 in the uppermost 0 to 0.2 and 0.8 to $1 \mathrm{~mm}$ of sediments, respectively) were used in our subsequent calculations of the actual irradiance intensity available for photosynthesis.

In addition, the microalgal biomass ( $\mathrm{chl}$ a) within the photosynthetic active layer was assumed not to be constant, as commonly adopted (Pinckney \& Zingmark 1993, Barranguet et al. 1998), but was calculated as decreasing with depth. An exponential equation was used, based on an averaged $52 \%$ reduction of chl a content from the surface $(0$ to $0.5 \mathrm{~cm})$ to the subsurface $(0.5$ to $2 \mathrm{~cm})$ layer, as obtained from HPLC measurements (Magni et al. 2000a). The decrease with depth was expressed by the following equation:

$$
y=100 \times 10^{-0.439 x}
$$

where $y$ is the percentage of chl a content reduction in the uppermost $2 \mathrm{~cm}$ of the sediments and $x$ is the depth of the sediments. The microphytobenthos biomass measured in surface sediments (0 to $0.5 \mathrm{~cm}$ ) during our routine survey (mean chl a content of the 5 stations) was then re-assessed in steps of $0.2 \mathrm{~mm}$ for the first $\mathrm{mm}$ (where the light intensity exponentially decreased to $3.2 \%$ at the 0.8 to $1 \mathrm{~mm}$ layer) and each $\mathrm{mm}$ for the next ones down to $5 \mathrm{~mm}$ depth. As such, only a minimal fraction of the total biomass measured in the uppermost $5 \mathrm{~mm}$ of sediments was considered as photosynthetic-competent, e.g. $10 \%$ of microphytobenthos biomass was calculated in the uppermost $0.4 \mathrm{~mm}$ as receiving ca. $77 \%$ of the total irradiance available for photosynthesis.
We subsequently calculated a photosynthetic rate factor (i.e. $f_{\mathrm{T}}$ ), described by the regression line $f_{\mathrm{T}}=$ $2.60 \times$ temperature $+48.1, \mathrm{r}^{2}=0.979$ and ranging between $f_{\mathrm{T}}=0.602\left(\right.$ at $4.7^{\circ} \mathrm{C}$ ) and $f_{\mathrm{T}}=1.208$ (at $29.8^{\circ} \mathrm{C}$ ), based on the results of our laboratory experiments on irradiance (I)- and temperature (T)-dependent photosynthetic rates $\left(\mu \mathrm{g} \mathrm{C} \mu \mathrm{g} \mathrm{chl} a^{-1} \mathrm{~h}^{-1}\right.$ ) of Navicula sp. This factor was then applied to the actual irradiance intensity available at each re-assessed photosynthetic competent layer to obtain an I- and T-dependent photosynthetic rate, and multiplied by the relevant fraction of microphytobenthos biomass calculated for each sub-layer.

The production of microphytobenthos was finally calculated for each photosynthetic sub-layer and summed as an all-layer production. These calculations were conducted for the 3 different situations and the 2 opposite, high and low, tidal states. Within-month variations of these 6 derived production estimates were always $<15 \%$. For each month, the mean was used to express the primary production of microphytobenthos on an areal basis as $\mathrm{gC} \mathrm{m}^{-2} \mathrm{~d}^{-1}$.

\section{RESULTS}

\section{Field surveys}

\section{Environmental variables}

Monthly mean air temperature at the sampling site varied from $4.7^{\circ} \mathrm{C}$ (February 1996) to $29.8^{\circ} \mathrm{C}$ (August 1995) (Fig. 2a), with an annual mean of $16.1 \pm 8.1^{\circ} \mathrm{C}$. Monthly mean solar radiation varied from 7.4 $\mathrm{MJ} \mathrm{m}^{-2}$ (December 1994 and January 1995) to $22.5 \mathrm{MJ} \mathrm{m}^{-2}$ (July 1994), with an annual mean of $13.8 \pm 4.1 \mathrm{MJ} \mathrm{m}^{-2}$. Solar radiation noticeably showed a temporary decrease every year in June (Fig. 2a). The rainfall was lowest in December 1995 (10 $\mathrm{mm} \mathrm{mo}^{-1}$ ) and peaked on several occasions, such as in September 1994, May and July 1995 (maximum of 335 mm mo-1), June 1996, and July 1997 (Fig 2b). In ebbing water (Stn H1), salinity widely varied between 1.3 psu (September 1996) and 32.1 psu (November 1995), sharply decreasing during rainfall events and being highest during periods of little rainfall (Fig. 2b). Annual mean salinity at Stn H1 was $17.5 \pm 10.6 \mathrm{psu}$. Also, water temperature at Stn H1 varied largely from $3.6^{\circ} \mathrm{C}$ (December 1995) to $32.2^{\circ} \mathrm{C}$ (July 1994) (Fig. 2C), with an annual mean of $17.1 \pm$ $8.6^{\circ} \mathrm{C} \mathrm{SD}$. Dissolved oxygen (DO) concentration showed a seasonal pattern, with a tendency to oversaturation between early spring and summer (maximum of $15.1 \mathrm{mg} \mathrm{l}^{-1}$ or $173 \%$ of air saturation in April 1996) (Fig. 2c). Annual mean of DO concentration was $8.4 \pm$ $2.6 \mathrm{mg} \mathrm{l}^{-1}$ or $94.4 \pm 32.3 \%$ of air saturation. 
Microphytobenthos biomass (chl a) in sediments

In surface sediments ( 0 to $0.5 \mathrm{~cm}$ ), the chl a content at individual stations ranged between $1.6 \mathrm{\mu g} \mathrm{g}^{-1}$ (Stn B4, June 1994) and $25.3{\mu g^{-1}}^{-1}$ (Stn B1, May 1995) (Fig. 3a). Spatial differences in chl a content between individual stations were limited to an annual mean significantly higher at Stns B3 (9.9 \pm $\left.4.6 \mu \mathrm{g} \mathrm{g}^{-1}\right)$ and B5 $\left(12.0 \pm 4.6 \mu \mathrm{g} \mathrm{g}^{-1}\right)$ than at Stn B4 $\left(8.8 \pm 4.1 \mu^{-1} g^{-1}\right)$ (ANOVA: single factor, $\mathrm{p}<0.001$ and $\mathrm{p}<0.05$, respectively, plots not shown). The chl a content at the subsurface layer ( 0.5 to $2 \mathrm{~cm}$ ) was constantly lower than that at the surface, displaying similar spatial and temporal variability (Fig. 3b), with a mean decrease of $34 \%(y$ [subsurface $]=0.49 x$ [surface $]+1.8$, $\mathrm{r}^{2}=0.64, \mathrm{n}=235$, ANOVA: $\mathrm{p}<0.001$, plots not shown). The investigations through the vertical profile of sediments at Stn B5 indicated a further and progressive decrease of chl a content with depth in all different seasons and irrespective of its standing stock (Fig. 4a). At this individual station, chl a varied from $1.3 \mathrm{\mu g} \mathrm{g}^{-1}$ (8 to $9 \mathrm{~cm}$, August 1995) to $20.0 \mathrm{\mu g} \mathrm{g}^{-1}$ (0 to $0.5 \mathrm{~cm}$, February 1996). At the surface, the chl a content accounted for $22.8 \pm 5.7 \mathrm{SD}$ of the total content in the uppermost $10 \mathrm{~cm}$ of the sediment, while it was lowest at the 9 to $10 \mathrm{~cm}$ layer with a mean of $3.2 \pm$ $1.4 \%$ (Fig. $4 \mathrm{~b}$ ).

(b)

(c)
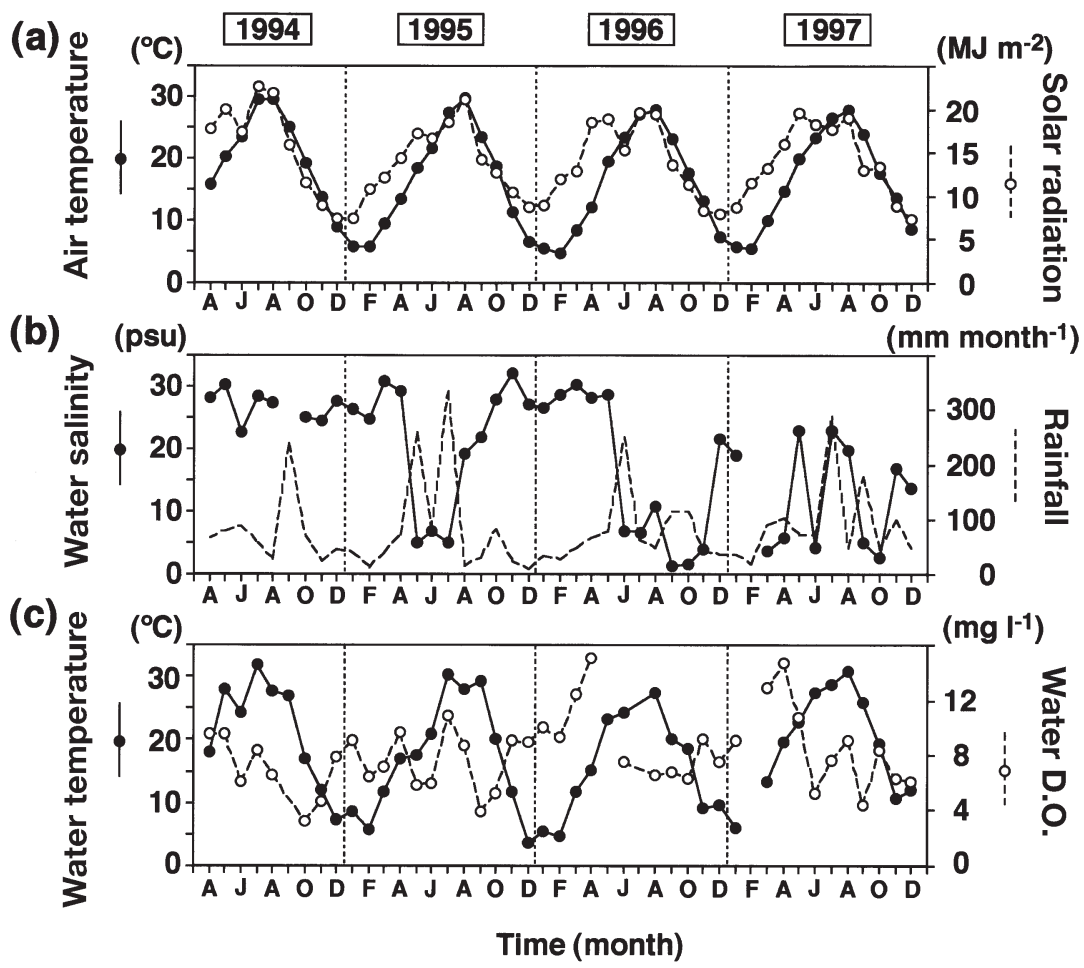

Fig. 2. Seasonal and interannual variability of environmental conditions at the study site. (a) Monthly mean of air temperature (left scale) and solar radiation (right scale). (b) Water salinity at Stn H1 (left scale) and monthly rainfall (right scale). (c) Water temperature (left scale) and dissolved oxygen concentrations (right scale) at Stn H1. Interrupted lines: data not available between 2 mo

Measurements of chl a content were also expressed on an areal basis ( $\mathrm{mg} \mathrm{chl} \mathrm{a} \mathrm{m}^{-2}$ ) by accounting for the bulk-density of the sediment particle as $2.5 \mathrm{~g} \mathrm{~cm}^{-3}$

(a) Surface $(0-0.5 \mathrm{~cm})$

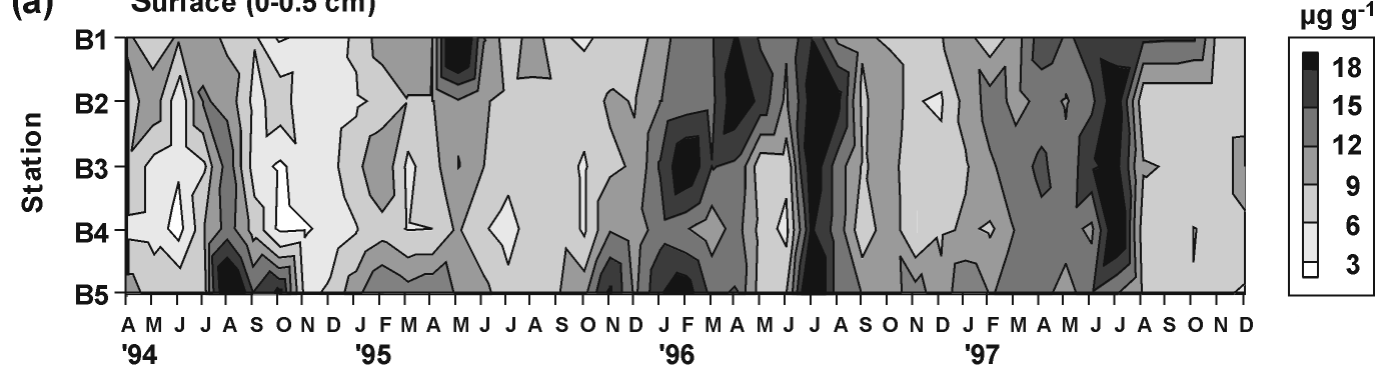

(b) Subsurface $(0.5-2 \mathrm{~cm})$

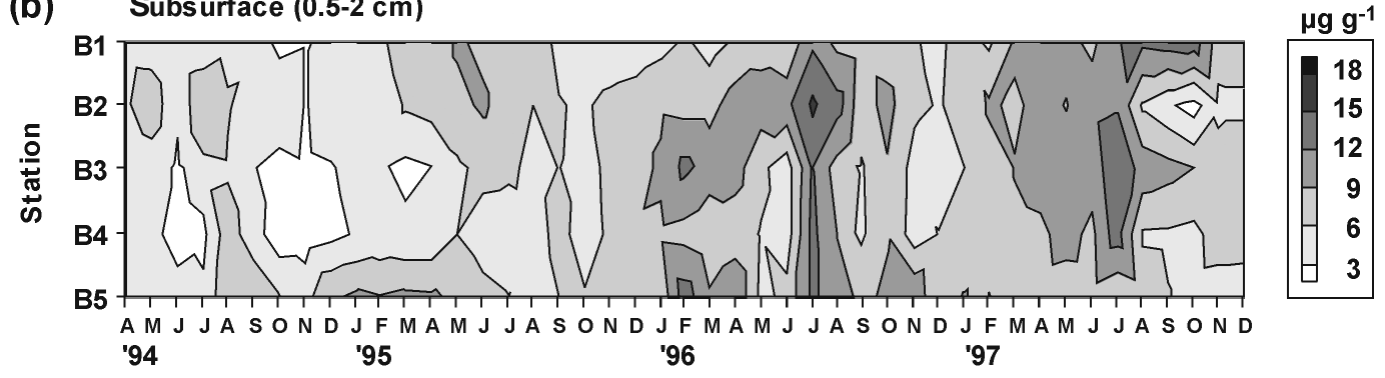

Fig. 3. Spatial and temporal distribution of microphytobenthos biomass ( $\mathrm{chl}$ a) at the 5 sampling stations (Stns B1 to B5) 

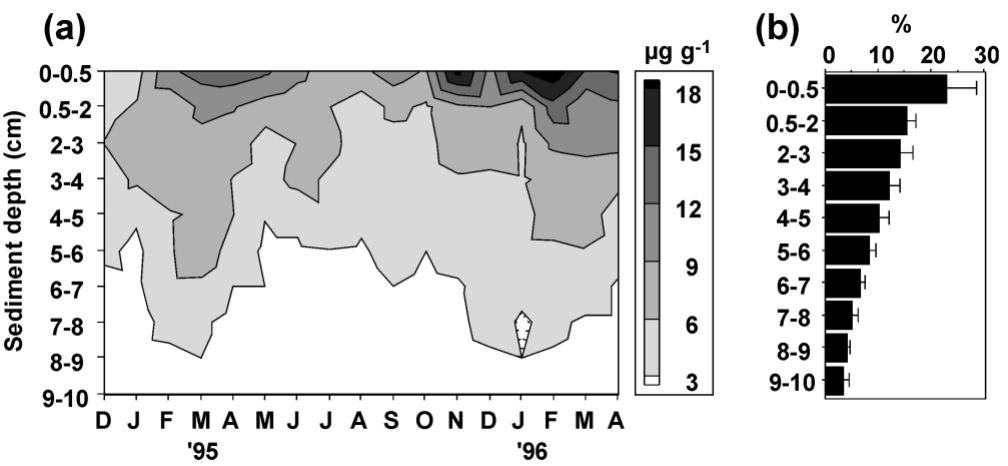

Fig. 4. Vertical distribution (0 to $10 \mathrm{~cm}$ depth) of microphytobenthic biomass (chl a) at Stn B5. (a) Chl a content. (b) Mean \pm SD of the relative percentage of chl a content at each layer during the period of investigations

5 stations. On a dry weight basis, the chl a content varied between $3.9 \pm 1.0 \mathrm{\mu g} \mathrm{g}^{-1}$ (November 1994) and $20.3 \pm 2.6 \mathrm{\mu g} \mathrm{g}^{-1}$ (July 1996), with an annual mean (1995 to 1997 period) of $11.0 \pm 4.3 \mathrm{\mu g} \mathrm{g}^{-1}$ (Table 1 ). On an areal basis, it varied between 27.7 $\pm 14.7 \mathrm{mg} \mathrm{m}^{-2}$ (October 1994) and $120.2 \pm$ $24.3 \mathrm{mg} \mathrm{m}^{-2}$ (July 1997), with an annual mean of $72.3 \pm 27.1 \mathrm{mg} \mathrm{m}^{-2}$ (Table 1$)$. In both cases, significant differences of chl a content between 2 subsequent sampling periods were restricted to a few and were irrespective of the season (Fig. 5). Yet the chl a content showed a clear seasonal pattern with a decrease every year between late summer and early autumn, and the

and taking into consideration the spatial and temporal variations of the porewater content. Accordingly, we calculated a factor $f$ from the ratio between the sediment particle bulk-density and the total volume, where the maximum value of $f=1$ is for a hypothetical sediment with $0 \%$ of porewater. Thus, this ratio changed depending on the different porewater content in each sample (not corrected for salinity) and varied from 0.20 (i.e. water content $61.2 \%$, Stn B5, October 1994) to 0.66 (i.e. water content $17.1 \%$, Stn B4, June 1994). The conversion equation was:

$$
\begin{aligned}
\mathrm{mg} \mathrm{chl} \mathrm{a} \mathrm{m}= & 5000 \mathrm{~cm}^{3} \mathrm{~m}^{-2} \times 2.5 \mathrm{~g} \mathrm{~cm}^{-3} \times \\
& f \times \mu \mathrm{g} \mathrm{chl} \mathrm{a} \mathrm{g} \mathrm{gW}^{-1} \text { sediment }
\end{aligned}
$$

The square regression line of all chl a plots was: $y=$ $5.43 x+10.7\left(\mathrm{r}^{2}=0.78, \mathrm{n}=235, \mathrm{p}<0.001\right)$, where $x$ and $y$ are the chl a content expressed as $\mu \mathrm{g} \mathrm{g}^{-1}$ and $\mathrm{mg} \mathrm{m}^{-2}$, respectively, indicating a good correlation of chl a estimates on a weight and an areal basis.

Fig. 5 shows the monthly estimates of microphytobenthos biomass in surface sediments, expressed in both ways, as a mean $( \pm \mathrm{SD})$ of chl a values from the lowest values in October during 1994 and 1995 (27.2 \pm 14.7 and $47.0 \pm 14.3 \mathrm{mg} \mathrm{m}^{-2}$, respectively) or in November during 1996 and 1997 (53.4 \pm 22.5 and $46.9 \pm$ $1.9 \mathrm{mg} \mathrm{m}^{-2}$, respectively). In addition, for 4 consecutive years, after a progressive increase in winter (i.e. $76.2 \pm$ 25.6 and $111 \pm 25.2 \mathrm{mg} \mathrm{m}^{-2}$ in February 1995 and 1996, respectively, and $76.8 \pm 21.3 \mathrm{mg} \mathrm{m}^{-2}$ in January 1997), the chl a content tended to decrease noticeably between May and June. This coincided with the temporary decrease of solar radation (Fig. 2a). The highest peaks of chl a occurred in April 1996 (116 $\pm 20.7 \mathrm{mg}$ $\mathrm{m}^{-2}$ ) and July $1997\left(120 \pm 24.3 \mathrm{mg} \mathrm{m}^{-2}\right)$. On a yearly basis, we found a significant trend of increasing microphytobenthos biomass from 1994 to 1997 (Table 1).

\section{Laboratory experiments}

Growth and production rate of Navicula sp.

Fig. 6 shows the results of the incubation experiments on the growth of Navicula sp. The chl a content of Navi-

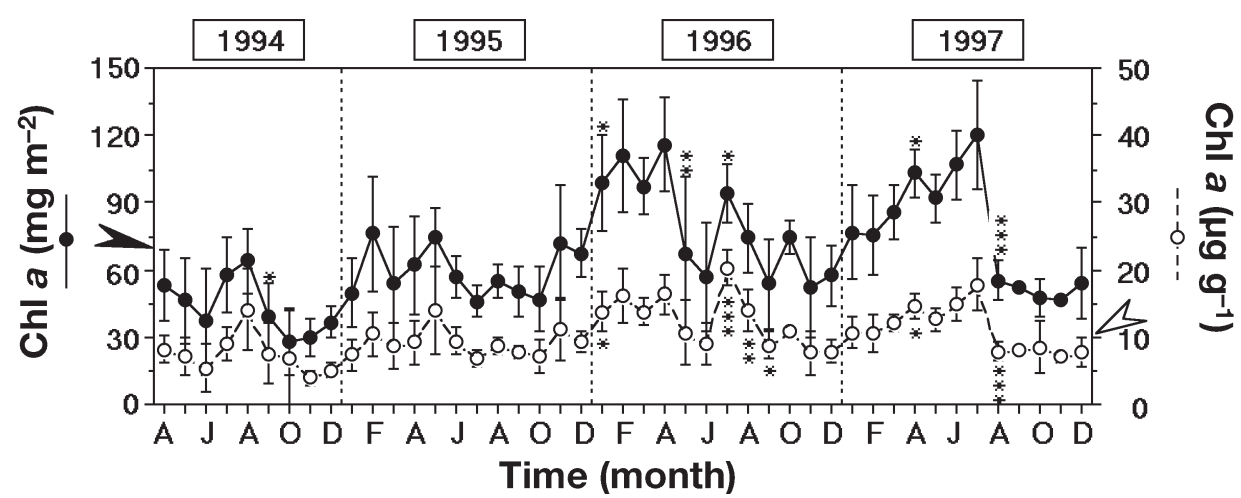

Fig. 5. Seasonal and interannual variability of microphytobenthic biomass (chl a), expressed as a mean \pm SD of the 5 sampling sta-

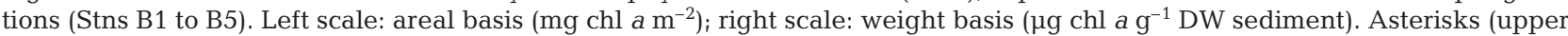
ones for the left scale and lower ones for the right scale) indicate significant difference between each sampling month and the previous one (ANOVA, ${ }^{*} \mathrm{p}<0.05,{ }^{* *} \mathrm{p}<0.01,{ }^{* * *} \mathrm{p}<0.001$ ) 
Table 1. Yearly means $( \pm \mathrm{SD})$ and ranges (minimum and maximum values) of microphytobenthos biomass (as chl a) in surface sediments $(0-0.5 \mathrm{~cm})$. ${ }^{*}$ April to December period; ${ }^{* *} 1995$ to 1997 period. ${ }^{a}$ and ${ }^{b}$ : significant differences between yearly estimates. DW: dry wt

\begin{tabular}{|c|c|c|c|}
\hline Year & & $\mu \mathrm{g}$ chl $a \mathrm{~g}^{-1} \mathrm{DW}^{\mathrm{a}}$ & $\mathrm{mg} \operatorname{chl} a \mathrm{~m}^{-2, b}$ \\
\hline $\begin{array}{l}\text { 1994* }^{*} \\
(\mathrm{n}=45)\end{array}$ & $\begin{array}{l}\text { Mean } \pm \text { SD } \\
(\text { min-max })\end{array}$ & $\begin{array}{c}7.5 \pm 4.6 \\
(1.6-24.1)\end{array}$ & $\begin{array}{l}43.5 \pm 18.6 \\
(12.9-84.1)\end{array}$ \\
\hline $\begin{array}{l}1995 \\
(\mathrm{n}=70)\end{array}$ & $\begin{array}{l}\text { Mean } \pm \text { SD } \\
(\min -\max )\end{array}$ & $\begin{array}{c}9.2 \pm 3.4 \\
(4.7-39.7)\end{array}$ & $\begin{array}{c}59.2 \pm 18.6 \\
(36.2-117.1)\end{array}$ \\
\hline $\begin{array}{l}1996 \\
(\mathrm{n}=60)\end{array}$ & $\begin{array}{l}\text { Mean } \pm \text { SD } \\
(\min -\max )\end{array}$ & $\begin{array}{l}12.6 \pm 4.7 \\
(4.8-24.5)\end{array}$ & $\begin{array}{l}79.9 \pm 29.0 \\
(25.9-39.8)\end{array}$ \\
\hline $\begin{array}{l}1997 \\
(n=60)\end{array}$ & $\begin{array}{l}\text { Mean } \pm \text { SD } \\
(\min -\max )\end{array}$ & $\begin{array}{l}12.1 \pm 7.0 \\
(5.5-21.7)\end{array}$ & $\begin{array}{c}78.7 \pm 27.7 \\
(37.7-145.5)\end{array}$ \\
\hline $\begin{array}{l}\text { Annual }^{* *} \\
(\mathrm{n}=190)\end{array}$ & $\begin{array}{l}\text { Mean } \pm \text { SD } \\
(\min -\max )\end{array}$ & $\begin{array}{l}11.0 \pm 4.3 \\
(1.6-39.7)\end{array}$ & $\begin{array}{c}72.3 \pm 27.1 \\
(12.9-145.5)\end{array}$ \\
\hline \multicolumn{4}{|c|}{$\begin{array}{l}\text { a } 1996 \text { and } 1997>1995(\text { ANOVA } \mathrm{p}<0.001) ; 1995>1994 \\
(\text { ANOVA } \mathrm{p}<0.05), \text { b1996 and } 1997>1995 \text { (ANOVA } \mathrm{p}< \\
0.001 \text { and } \mathrm{p}<0.01 \text { ) }\end{array}$} \\
\hline
\end{tabular}

cula sp. was measured to be $2.14 \mathrm{pg}$ chl a cell ${ }^{-1}$. Accordingly, the cell number increase of Navicula sp. during the incubation period was calculated from the mean of replicate measurements of chl a content tube ${ }^{-1}$ (Fig. 6). The exponential growth of Navicula sp. lasted for $6 \mathrm{~d}$ before reaching steady state (Fig. 6). From these results, the growth rate factor of Navicula sp. was $\mu=1.68 \mathrm{~d}^{-1}$.

The photosynthetic rate was saturated at a light intensity of $165 \mu \mathrm{E} \mathrm{m}^{-2} \mathrm{~s}^{-1}$ at $21^{\circ} \mathrm{C}$ (Fig. $7 \mathrm{a}$ ). At this light intensity, the $P_{\max }$ (maximum photosynthetic capacity) was $7.9 \mu \mathrm{g} \mathrm{C} \mu \mathrm{g} \mathrm{chl} a^{-1} \mathrm{~h}^{-1}$. There was no photoinibition at higher light intensities of up to $400 \mu \mathrm{E} \mathrm{m}^{-2} \mathrm{~s}^{-1}$. The photosynthetic rate was expressed by the following equation from Jassby \& Platt (1976):

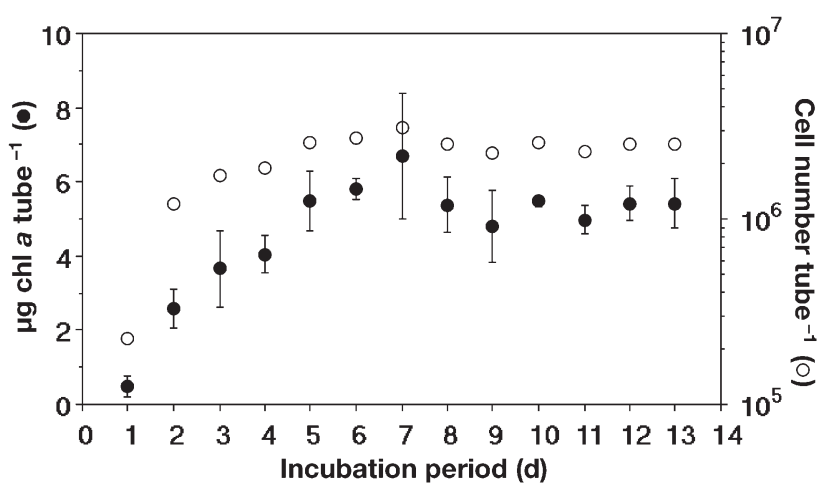

Fig. 6. Laboratory experiments on the growth rate by Navi-

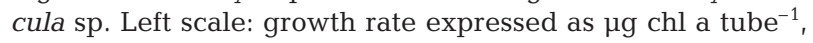
SD of triplicate cultures of Navicula sp.; right scale: growth rate expressed as cell number tube ${ }^{-1}$. This was calculated from the mean of triplicate measurements, where the chl a content of Navicula sp. is $2.14 \mathrm{pg} \mathrm{chl} \mathrm{a} \mathrm{cell}{ }^{-1}$

$$
y=7.85-\tanh [(0.0785-x) / 7.85]
$$

where $y$ is the photosynthetic rate and $x$ is the light intensity (Fig. 7a).

The relationship between temperature and photosynthetic rate was linear and positive within a fieldrelevant temperature range of 10 to $35^{\circ} \mathrm{C}$ at $55 \mu \mathrm{E} \mathrm{m}{ }^{-2}$ $\mathrm{s}^{-1}$ (Fig. 7b).

\section{Elemental composition of Navicula sp.}

The weight ratio between biophilic elements ( $C, N, P$ and $\mathrm{Si}$ ) and chl $a$ in Navicula sp. was: C/chl $a=33.7 \pm$ $5.60(\mathrm{n}=17), \mathrm{N} / \mathrm{chl} a=5.58 \pm 1.27(\mathrm{n}=17), \mathrm{P} / \mathrm{chl} a=$ $1.15 \pm 0.312(\mathrm{n}=10), \mathrm{Si} / \mathrm{chl} a=18.5 \pm 1.31(\mathrm{n}=4)$. Accordingly, the molar ratio was: $\mathrm{C} / \mathrm{N}=7.05 \pm 0.81$ and $\mathrm{C}: \mathrm{N}: \mathrm{P}: \mathrm{Si}=75.7: 10.1: 1: 17.8$.

\section{Patterns of microphytobenthos primary production}

Our scaling up of production estimates to areal primary production of microphytobenthos was calculated

\section{Photosynthetic rate}
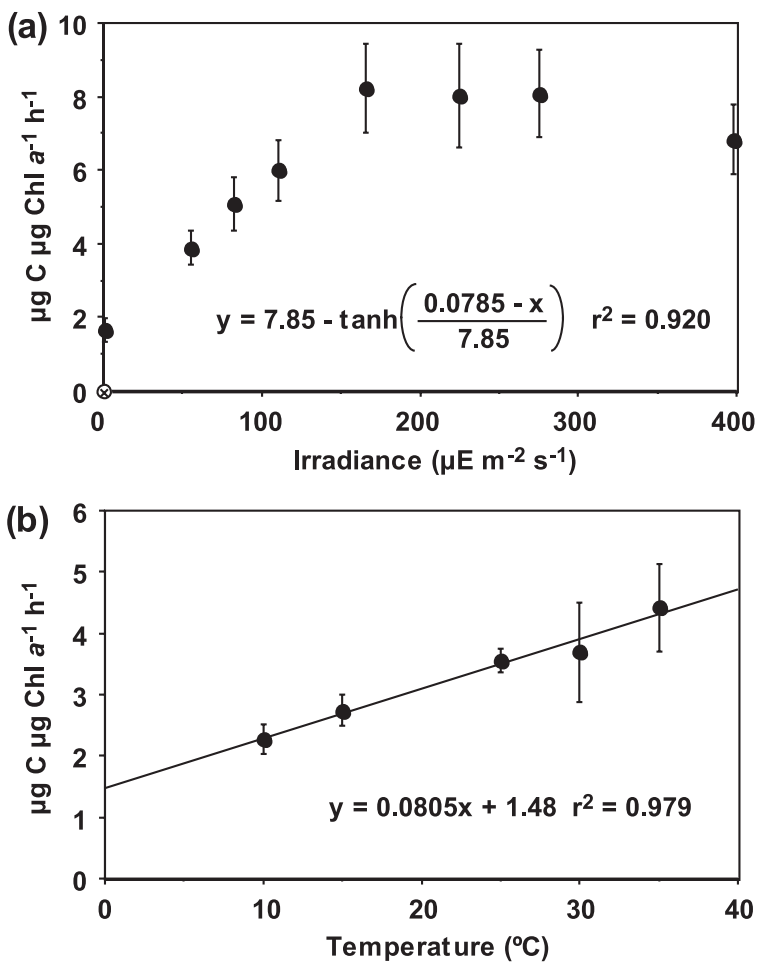

Fig. 7. Laboratory experiments on the photosynthetic rate of Navicula sp. (a) Photosynthetic rate irradiance-dependent at $21^{\circ} \mathrm{C}$ indicated is the mean $\pm \mathrm{SD}$ of 3 to 7 replicate measurements for each irradiance intensity (i.e. 0.7, 55, 110, 165, 225, 276 and $398 \mu \mathrm{E} \mathrm{m}^{-2} \mathrm{~s}^{-1}$ ). (b) Photosynthetic rate temperaturedependent at $55 \mu \mathrm{E} \mathrm{m}{ }^{-2} \mathrm{~s}^{-1}$; indicated is the mean \pm SD of 2 to 3 replicate measurements for each temperature level 


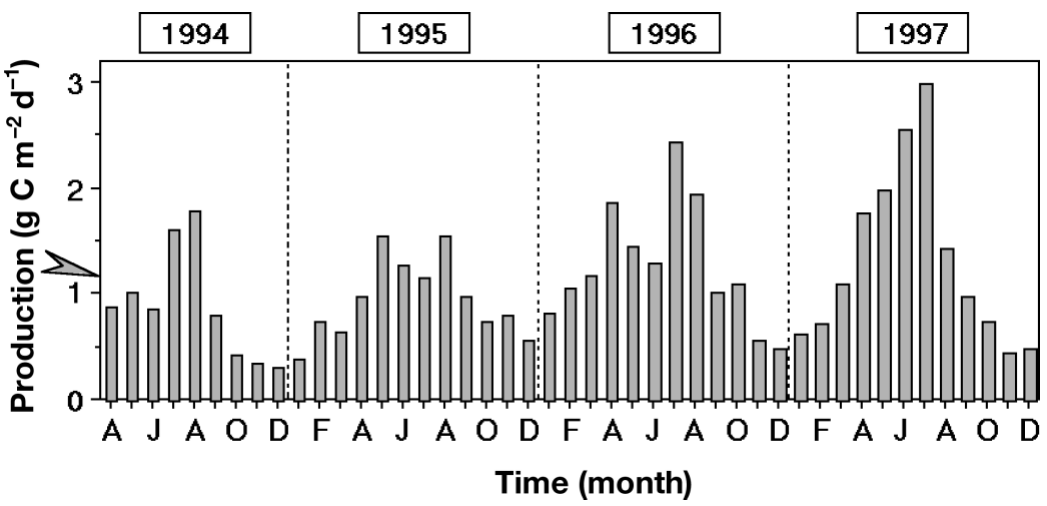

Fig. 8. Quantification of seasonal and interannual variability primary production $\left(\mathrm{gC} \mathrm{m}^{-2} \mathrm{~d}^{-1}\right)$ of microphytobenthos in the study area $\mathrm{m}^{-2}$ (top $1 \mathrm{~cm}$ ) in Savin Hill Cove, Boston (Gould \& Gallagher 1990), 72 to $102 \mathrm{mg} \mathrm{m}^{-2}$ (top $5 \mathrm{~mm}$ ) in the North Inlet of South Carolina (Pinckney \& Zingmark 1993), $113 \mathrm{mg} \mathrm{m}^{-2}$ (7.3 $\mu \mathrm{g}$ $\mathrm{g}^{-1}$ ) (top $1 \mathrm{~cm}$, De Jong \& De Jonge 1995 ) or $5.9 \mathrm{mg} \mathrm{m}^{-2}$ (sand) to $17.3 \mathrm{mg}$ $\mathrm{m}^{-2}$ (muddy) (top $1 \mathrm{~mm}$, Barranguet et al. 1998) in the Westerschelde. In our study area, the annual mean of microphytobenthos biomass was $72.3 \pm$ $27.1 \mathrm{mg} \mathrm{chl} \mathrm{a} \mathrm{m}{ }^{-2}$ or $11.0 \pm 4.3 \mu \mathrm{g} \mathrm{chl} \mathrm{a}$ $\mathrm{g}^{-1}$ (Table 1). Whereas chl a estimates expressed either on a weight or an areal basis might be loosely correlated with each others if the sedimentspecific weight varies considerably, and varyied up to an order of magnitude from $0.32 \mathrm{~g} \mathrm{C}$ $\mathrm{m}^{-2} \mathrm{~d}^{-1}$ (December 1994) to $3.0 \mathrm{~g} \mathrm{C} \mathrm{m}^{-2} \mathrm{~d}^{-1}$ (July 1997), with an annual mean (1995 to 1997) of $1.2 \mathrm{~g} \mathrm{C} \mathrm{m}^{-2} \mathrm{~d}^{-1}$ (Fig. 8). Seasonal patterns and interannual variability were also observed. Uni-modal (summer) or bi-modal (spring and summer) peaks occurred in 1994 to 1997 and 1995 to 1996, respectively, with a marked decrease every year from late autumn to early winter, and a tendency to increasing annual estimates from 1995 to 1997. Regardless of the year, primary production was significantly higher both in spring and summer than in winter (ANOVA: $p<0.001$ ) and fall (ANOVA: $p<0.005$ and $<0.001$, respectively) (Table 2 ).

\section{DISCUSSION}

\section{Spatial and temporal distribution of microphytobenthos}

Microphytobenthos biomass has been investigated in various intertidal sediments around the world at different latitudes (MacIntyre 1996 and references therein), spatial and temporal scales, and sediment types (Colijn \& Dijkema 1981, De Jong \& De Jonge 1995, Magni \& Montani 1997). Although different methodological approaches may concur to limit comparisons among different studies, there is rather consistent literature on the quantification and variability of microphytobenthos biomass in these systems. The determination of chl a content is widely used to quantify the living fraction of microalgal assemblages in surface sediments. Chl a estimates of microphytobenthos biomass amounted to ca. $100 \mathrm{mg} \mathrm{m}^{-2}$ (top $0.75 \mathrm{~cm}$ ) in south New England (Marshall et al. 1971), 3.8 to $11.3 \mathrm{\mu g} \mathrm{g}^{-1}$ (top $1 \mathrm{~cm}$ ) in the Wadden Sea (Cadée \& Hegeman 1974), 33 to $184 \mathrm{mg} \mathrm{m}^{-2}$ (top $5 \mathrm{~mm}$ ) in the Ems-Dollard (Colijn \& De Jonge 1984), 50 to $330 \mathrm{mg}$ this was not the case in our study area (see 'Results'), which was characterized by a relatively homogeneous sandy sediment. Sandy sediments tend to have a lower chl a content than muddy sediments (Colijn \& Dijkema 1981, De Jong \& De Jonge 1995, Magni \& Montani 1997), comparison of our estimates with those from other sites indicate that microphytobenthic biomass at our site, expressed both as $\mathrm{mg} \mathrm{chl} \mathrm{a} \mathrm{m}^{-2}$ and $\mu \mathrm{g}$ chl a $\mathrm{g}^{-1}$, rank in the mid-upper range of for intertidal sediments (see also Table 4 in Colijn \& De Jonge 1984, and Table 3 in MacIntyre et al. 1996).

Although a lot of literature exists on the development of intertidal microphytobenthos at different sites, and on the multiplicity of abiotic and biotic controlling factors (but see also Pinckney \& Zingmark 1991), little information is as yet available on the distribution of microphytobenthic assemblages within an individual system at various spatial scales (i.e. horizontal and vertical), in combination with an evaluation of seasonal

Table 2. Seasonal means $( \pm \mathrm{SD})$ and ranges (minimum and maximum values) of microphytobenthos primary production $\left(\mathrm{g} \mathrm{C} \mathrm{m}^{-2} \mathrm{~d}^{-1}\right)$. ${ }^{*} 1995$ to 1997 period

\begin{tabular}{|c|c|c|}
\hline $\begin{array}{l}\text { Winter (Dec to Feb) } \\
(\mathrm{n}=10)\end{array}$ & $\begin{array}{l}\text { Mean } \pm \text { SD } \\
(\min -\max )\end{array}$ & $\begin{array}{l}0.63 \pm 0.33 \\
(0.32-1.07)\end{array}$ \\
\hline $\begin{array}{l}\text { Spring (Mar to May) } \\
(\mathrm{n}=11)\end{array}$ & $\begin{array}{l}\text { Mean } \pm \text { SD } \\
(\min -\max )\end{array}$ & $\begin{array}{l}1.32 \pm 0.44 \\
(0.66-2.01)\end{array}$ \\
\hline $\begin{array}{l}\text { Summer (Jun to Aug) } \\
(\mathrm{n}=12)\end{array}$ & $\begin{array}{l}\text { Mean } \pm \text { SD } \\
(\min -\max )\end{array}$ & $\begin{array}{l}1.75 \pm 0.63 \\
(0.88-3.00)\end{array}$ \\
\hline $\begin{array}{l}\text { Fall (Sep to Nov) } \\
(\mathrm{n}=12)\end{array}$ & $\begin{array}{l}\text { Mean } \pm \text { SD } \\
(\min -\max )\end{array}$ & $\begin{array}{l}0.75 \pm 0.25 \\
(0.34-1.10)\end{array}$ \\
\hline $\begin{array}{l}\text { Annual }^{*} \\
(\mathrm{n}=36)\end{array}$ & $\begin{array}{l}\text { Mean } \pm \text { SD } \\
(\min -\max )\end{array}$ & $\begin{array}{l}1.19 \pm 0.63 \\
(0.40-3.00)\end{array}$ \\
\hline Spring $>$ Winter & $($ ANOVA $p<0.001)$ & \\
\hline Spring > Fall & $($ ANOVA $\mathrm{p}<0.005)$ & \\
\hline Summer $>$ Winter & $($ ANOVA $p<0.001)$ & \\
\hline Summer > Fall & $($ ANOVA $p<0.001)$ & \\
\hline
\end{tabular}


and interannual patterns (Cadée \& Hegeman 1974, Riaux-Gobin 1985, Peletier 1996). Our monitoring survey was carried out regularly on a monthly basis over an extended (interannual) period and at a controlled spring low tide of every month, in order to allow us to interpret the results in a coherent and consistent way. Both environmental variability and the spatio-temporal distribution of microphytobenthos in our study area could be thus evaluated from a seasonal and interannual standpoint and for that particular tidal state. Clearly, it was not our intention here to investigate the variability of these ecosystems inherent to shorter (i.e. hours, days) temporal scales (Stevenson 1983, Pinckney \& Zingmark 1991, Barranguet et al. 1998, Kromkamp et al. 1998, Montani et al. 1998, Kingston 1999, Blanchard et al. 2001). This study indicated that there was a strong seasonal and interannual variability in the occurrence and development of microphytobenthic assemblages on the flat under investigation, displaying each year either uni- or bi-modal peaks. Latewinter (February) peaks occurred in 1995 and 1996, as was reported by several other authors (Colijn \& Dijkema 1981, Pinckney \& Zingmark 1993 and references therein) and also found in our previous study on the same flat (Magni \& Montani 1997). In the Westerschelde, De Jong \& De Jonge (1995) reported 1 large peak in early summer (May to June). In our study area, this period coincided with a seasonal reduction of irradiance (Fig. 2a) and a parallel decrease of microphytobenthic biomass (Fig. 5). Subsequently, summer peaks (i.e. July to August), noticeable in 1994 and highest in 1996 and 1997 (Fig. 5), also occurred as a second bloom, which was similar to that found by Montagna et al. (1983) at a higher latitude. In contrast, a summer peak was absent in 1995 and a sharp decrease of chl a content occurred in August 1997. In both cases, the marked reduction of microphytobenthic biomass coincided with periods of increased rainfall (Fig. 2b), suggesting that rainfall events effectively flushed away microphytobenthic assemblages, as has been documented elsewhere (Magni \& Montani 1997).

\section{Laboratory experiments on microphytobenthos production}

Effect of light and temperature, and assimilation rates

Estimated photosynthesis-irradiance $(P-I)$ curves for intertidal microphytobenthos have been shown to be variable in the literature, depending on species/ assemblages composition. An early study by Colijn \& Van Buurt (1975) indicated rates of photosynthesis similar to ours using cultures of Amphiprora cf. paludosa grown at $20^{\circ} \mathrm{C}$ and 74 or $129 \mu \mathrm{E} \mathrm{m}^{-2} \mathrm{~s}^{-1}$. Admiraal
(1977) found that the minimum daily quantum irradiance for light-saturated growth of 4 intertidal microphytobenthic species was 85 to $170 \mu \mathrm{E} \mathrm{m}^{-2} \mathrm{~s}^{-1}$, and was not greatly influenced by the 2 experimental temperatures (i.e. 12 and $20^{\circ} \mathrm{C}$ ). More recently, other authors reported light intensity saturation at ca. $1000 \mu \mathrm{E} \mathrm{m} \mathrm{m}^{-2} \mathrm{~s}^{-1}$. For instance in Pinckney \& Zingmark (1991) and Blanchard et al. (1996), photosynthesis by microphytobenthos (intact cores and isolated motile diatoms, respectively) became light-saturated for scalar irradiance greater than $600 \mu \mathrm{E} \mathrm{m}^{-2} \mathrm{~s}^{-1}$, and was not photoinhibited up to 1800 and $1200 \mu \mathrm{E} \mathrm{m} \mathrm{m}^{-2} \mathrm{~s}^{-1}$, respectively. Conversely, lower $E_{\max }$ (irradiance intensity at which $P_{\max }$ maximal production rate, is reached) has been reported in the Wadden Sea. On the tidal flat of Keitum, Germany, photoinhibition occurred at irradiance higher than $861 \mu \mathrm{E} \mathrm{m}^{-2} \mathrm{~s}^{-1}$, with $E_{\max }$ between 345 and $655 \mu \mathrm{E}$ $\mathrm{m}^{-2} \mathrm{~s}^{-1}$ (at $18 \pm 1^{\circ} \mathrm{C}$ ) (Hartig et al. 1998). Even lower $E_{\max }$ was found on a Danish flat in the Wadden Sea, where the photosynthetic rate was saturated at light intensity of $160 \mu \mathrm{E} \mathrm{m} \mathrm{m}^{-2} \mathrm{~s}^{-1}$ at $4^{\circ} \mathrm{C}, 175 \mu \mathrm{E} \mathrm{m}{ }^{-2} \mathrm{~s}^{-1}$ at $18^{\circ} \mathrm{C}$ and $360 \mu \mathrm{E} \mathrm{m}^{-2} \mathrm{~s}^{-1}$ at $9^{\circ} \mathrm{C}$ (Rasmussen et al. 1983). In our laboratory experiments, Navicula sp. reached the $E_{\max }$ at $165 \mu \mathrm{E} \mathrm{m} \mathrm{m}^{-2} \mathrm{~s}^{-1}$ at $21^{\circ} \mathrm{C}$. Our values are therefore in close approximation with those reported by Rasmussen et al. (1983). These values are also rather similar to those for sublittoral microphytobenthic communities, measured as ${ }^{14} \mathrm{C}$ uptake and varying between 30 and $320 \mu \mathrm{E} \mathrm{m} \mathrm{m}^{-2} \mathrm{~s}^{-1}$ (Sundbäck \& Jönsson 1988), and for planktonic diatoms reaching light saturation at irradiance greater than $220.6 \mu \mathrm{E} \mathrm{m}^{-2} \mathrm{~s}^{-1}$ (Ryther 1956).

As for temperature, Admiraal (1977) found that at $85 \mu \mathrm{E} \mathrm{m}{ }^{-2} \mathrm{~s}^{-1}$ the highest growth rates of Navicula arenaria occurred at between 16 and $20^{\circ} \mathrm{C}$, while Amphiprora cf. paludosa, Nitzschia dissipata and Nitzschia sigma had their optimum temperature at $25^{\circ} \mathrm{C}$ or higher. Blanchard et al. (1996) estimated that while $P_{\max }$ was almost twice as high in September as in December, $T_{\text {opt }}$ did not change and was ca. $25^{\circ} \mathrm{C}$. Our physiological measurements showing a linear increase of photosynthesis rate by Navicula sp. within a temperatures range of 10 to $35^{\circ} \mathrm{C}$ suggests that temperature might be less limiting than light.

Also assimilation rates are rather variable in the literature. Admiraal (1977) reported for Nitzschia dissipata and Navicula arenaria assimilation values of 2 to

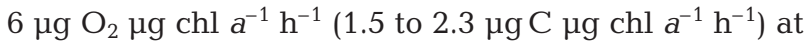
$20^{\circ} \mathrm{C}$ and $74 \mu \mathrm{E} \mathrm{m}^{-2} \mathrm{~s}^{-1}$. In a subsequent paper (Admiraal \& Peletier 1980), the assimilation rates of 4 benthic diatom species (Navicula salinarum, N. arenaria, Gyrosigma spencerii and Amphiprora cf. paludosa) ranged between 7 and $13 \mu \mathrm{g} \mathrm{C} \mu \mathrm{g} \mathrm{chl} a^{-1} \mathrm{~h}^{-1}$. As described earlier, in our laboratory experiments, the assimilation number of Navicula sp. was $3.89 \pm 0.45 \mu \mathrm{g} \mathrm{C} \mu \mathrm{g} \mathrm{chl} a^{-1}$ $\mathrm{h}^{-1}$ at $21^{\circ} \mathrm{C}$ and $55.2 \mu \mathrm{E} \mathrm{m} \mathrm{m}^{-2} \mathrm{~s}^{-1}$. We infer that discrep- 
ancies between authors may be to some extent related to methodological differences and/or differences between species.

Elemental ratios of Navicula sp.

The $\mathrm{C} / \mathrm{chl}$ a ratio calculated in this study for Navicula sp. $(33.7 \pm 5.6, \mathrm{n}=17)$ is very similar to that earlier indicated for phytoplankton (Parsons \& Strickland 1959) and more recently for Bacillariophyceae (Montagnes et al. 1994). Our results are also in good agreement with values previously reported for intertidal microphytobenthos. De Jonge (1980) reported a variability of the C/chl a ratio between 40.3 and 61.4, in Gould \& Gallagher (1990) this ratio varied from 18.7 to 60.4 . Accordingly, the $\mathrm{N} / \mathrm{chl}$ a ratio $(5.58 \pm 1.27, \mathrm{n}=17)$ and the $\mathrm{C} / \mathrm{N}$ ratio $(7.05 \pm 0.81)$ are also within the range reported in the literature (Perry 1976, Montagnes et al. 1994), whereas the $\mathrm{Si} / \mathrm{chl} a$ and $\mathrm{P} / \mathrm{chl}$ a ratios (18.5 \pm 1.31 and $1.15 \pm 0.31$, respectively) indicate that Navicula sp. has a high $\mathrm{P}$ content relative to the Redfield et al. (1963) ratio.

\section{Areal primary production of microphytobenthos}

Our extrapolation and scaling up of production estimates to a field-relevant situation principally was aimed at investigating the extent and magnitude of seasonal and interannual variability and/or patterns, if any. We concurrently acknowledge that our areal estimates may be referred as to 'potential' primary production of microphytobenthos for our study area, also considering that our derived rates are based on optimal conditions for photosynthesis of a predominant microphytobenthic species. However, we infer that the magnitude and scope of our approach, surpassing the short-term (hours, days) field variability and speciesspecific differences of physiological responses among microphytobenthic communities, allowed us to unravel long-term scales and patterns of intertidal microphytobenthos assemblages and development. Attempts to investigate the interannual distribution of both biomass and microphytobenthos primary production are very scarce indeed; this is also due to temporal restrictions and concrete difficulties in extrapolating physiological measurements to large-scale trends. In addition, although it is true that biomass measurements in the field were made during daytime at low tide when production rates of microphytobenthos have been shown to be maximal (Pinckney \& Zingmark 1991), areal production estimates were obtained by applying the physiological rates of Navicula sp. to the minimal field-relevant fraction of microphytobenthos biomass in the photosynthetic active layer of sediments. This was calculated to be mainly restricted to the uppermost $0.2 \mathrm{~mm}$ of sediments which only represented $10 \%$ of total microphytobenthos biomass in surface sediments and where $77 \%$ of the total irradiance was available for primary production. Based on this theoretically derived approach, primary production of microphytobenthos indicated clear interannual patterns (Fig. 8), with significant differences between seasons (Table 2). Among the few examples of long-term variability, De Jong et al. (1994) reported for the Eastern Scheldt estuary that primary production of microphytobenthos increased from 1981 to 1990 from 150 to $242 \mathrm{gC} \mathrm{m}^{-2} \mathrm{yr}^{-1}$, which accounted for 16 and $30 \%$ of the total primary production, respectively. In the Western Scheldt estuary, the contribution of the microphytobenthos to the total primary production was estimated to be at least $17 \%$ (De Jong \& De Jonge 1995). Even stronger contribution to the autochthonous source of carbon from microbial production has been reported on an intertidal flat in SW England, where the annual primary production for the sediment and the water column was 143 and $81.7 \mathrm{~g} \mathrm{C} \mathrm{m}^{-2} \mathrm{yr}^{-1}$, respectively. In our study, annual primary production of microphytobenthos (434 $\mathrm{gC} \mathrm{m}^{-2} \mathrm{yr}^{-1}$; Table 2) was higher than that reported on the phytoplankton in the eutrophic Seto Inland Sea $\left(285 \mathrm{~g} \mathrm{C} \mathrm{m}^{-2} \mathrm{yr}^{-1}\right.$; Tada et al. 1998), suggesting a high productivity of this intertidal zone, in addition to the strong seasonality of both microphytobenthos biomass and primary production.

Acknowledgements. We gratefully acknowledge Miss M. Shimamoto and the students of the Laboratory of Environmental Oceanography, Kagawa University, for their cooperation during the field work throughout the years. Dr. K. Tada, associate professor at Kagawa University, and Mr. Yamaguchi of the same University are also thanked for their comments.

\section{LITERATURE CITED}

Admiraal W (1977) Influence of light and temperature on the growth rate of estuarine benthic diatoms in culture. Mar Biol 39:1-9

Admiraal W, Peletier H (1980) Influence of seasonal variations of temperature and light on the growth rate of culture and natural population of intertidal diatoms. Mar Ecol Prog Ser $2: 35-43$

Barranguet C, Kromkamp J, Peene J (1998) Factor controlling primary production and photosynthetic characteristics of intertidal microphytobenthos. Mar Ecol Prog Ser 173: $117-126$

Blanchard GF, Guarini JM, Richard P, Gros P, Mornet F (1996) Quantifying the short-term temperature effect on lightsaturated photosynthesis of intertidal microphytobenthos. Mar Ecol Prog Ser 134:309-313

Blanchard GF, Guarini JM, Orvain F, Sauriau PG (2001) Dynamic behaviour of benthic microalgal biomass in intertidal mudflats. J Exp Mar Biol Ecol 264:85-100

Burford MA, Long BG, Rothlisberg PC (1994) Sedimentary 
pigments and organic carbon in relation to microalgal and benthic fauna abundance in the Gulf of Carpentaria. Mar Ecol Prog Ser 103:111-117

Cadée GC, Hegeman J (1974) Primary production of the benthic microflora living on tidal flats in the Dutch Wadden Sea. Neth J Sea Res 8:260-291

Cadée GC, Hegeman J (1977) Distribution of primary production of the benthic microflora and accumulation of organic matter on a tidal flat area, Balgzand, Dutch Wadden Sea. Neth J Sea Res 11:24-41

Cammen LM (1991) Annual bacterial production in relation to benthic microalgal production and sediment oxygen uptake in an intertidal sandflat and an intertidal mudflat. Mar Ecol Prog Ser 71:13-25

Colijn F, Van Buurt G (1975) Influence of light and temperature on the photosynthetic rate of marine benthic diatoms. Mar Biol 31:209-214

Colijn F, De Jonge VN (1984) Primary production of microphytobenthos in the Ems-Dollard Estuary. Mar Ecol Prog Ser 14:185-196

Colijn F, Dijkema KS (1981) Species composition of benthic diatoms and distribution of chl $a$ on an intertidal flat in the Dutch Wadden Sea. Mar Ecol Prog Ser 4:9-21

De Jong DJ, De Jonge VN (1995) Dynamics and distribution of microphytobenthic chl $a$ in the Western Schelde estuary (SW Netherlands). Hydrobiologia 311:21-30

De Jong DJ, Nienhuis PH, Kater BJ (1994) Microphytobenthos in the Oosterschelde estuary (The Netherlands), 1981-1990; consequences of a changed tidal regime. Hydrobiologia 282/283:183-195

De Jonge VN (1980) Fluctuations in the organic carbon to chl a ratios for estuarine benthic diatom populations. Mar Ecol Prog Ser 104:185-196

Delgado M (1989) Abundance and distribution of microphytobenthos in the bays of Ebro delta (Spain). Estuar Coast Shelf Sci 29:183-194

Dring MJ, Lüning K (1994) Influence of spring-neap tidal cycles on the light available for photosynthesis by benthic marine plants. Mar Ecol Prog Ser 104:131-137

Gould DM, Gallagher ED (1990) Field measurement of specific growth rate, biomass, and primary production of benthic diatomn of Savin Hill Cove, Boston. Limnol Oceanogr 35:1757-1770

Guarini JM, Blanchard GF, Bacher C, Gros P and 6 others (1998) Dynamics of spatial patterns of microphytobenthic biomass: interferences from a geostatistical analysis of two comprehensive surveys in Marennes-Oléron Bay (France). Mar Ecol Prog Ser 166:131-141

Hartig P, Wolfstein K, Lippemeier S, Colijn F (1998) Photosynthetic activity of natural microphytobenthos populations measured by fluorescence (PAM) and ${ }^{14} \mathrm{C}$-tracer methods: a comparison. Mar Ecol Prog Ser 166:53-62

Heip CHR, Goosen NH, Herman PMJ, Kromkamp J, Middelburg JJ, Soetart K (1995) Production and consumption of biological particles in temperate tidal estuaries. Oceanogr Mar Biol Annu Rev 33:1-149

Jassby AS, Platt T (1976) Mathematical formulation of the relationship between photosynthesis and light for phytoplankton. Limnol Oceanogr 21:540-547

Kingston MB (1999) Wave effects on the vertical migration of two benthic microalgae: Hantzschia virgata var. intermedia and Euglena proxima. Estuaries 22:81-91

Kromkamp J, Barranguet C, Peene J (1998) Determination of microphytobenthos PSII quantum efficiency and photosynthetic activity by means of variable chlorophyll fluorescence. Mar Ecol Prog Se 162:45-55

Lorenzen CJ (1967) Determination of chlorophyll and pheo- pigments: spectrophotometric equations. Limnol Oceanogr 12:343-346

Lukatelick RJ, McComb AJ (1986) Distribution and abundance of benthic microalgae in a shallow southwestern Australian estuarine system. Mar Ecol Prog Ser 27: 287-297

MacIntyre HL, Geider RJ, Miller DG (1996) Microphytobenthos: the ecological role of the 'secret garden' of unvegetated, shallow-water marine habitats. I. Distribution, abundance and primary production. Estuaries 19:186-201

Magni P (1998) A multidisciplinary study on the dynamics of biophilic elements $(C, N, P, S i)$ in a tidal estuary of the Seto Inland Sea, Japan: physico-chemical variability and macrozoobenthic communities. PhD thesis, The United Graduate School of Ehime University, Ehime

Magni P, Montani S (1997) Development of benthic microalgal assemblages on an intertidal flat in the Seto Inland Sea, Japan: effects of environmental variability. La Mer 35:137-148

Magni P, Montani S (1998) Responses of intertidal and subtidal communities of the macrobenthos to organic load and oxygen depletion in the Seto Inland, Japan. J Res Oceanogr 23:47-56

Magni P, Montani S (2000) Water chemistry variability in the lower intertidal zone of a tidal estuary in the Seto Inland Sea, Japan: seasonal patterns of dissolved and particulate compounds. Hydrobiologia 432:9-23

Magni P, Abe N, Montani S (2000a) Quantification of microphytobenthos biomass in intertidal sediments: layerdependent variation of chl a content determined by spectrophotometric and HPLC methods. La Mer 38:57-63

Magni P, Montani S, Takada C, Tsutsumi H (2000b) Temporal scaling and relevance of bivalve nutrient excretion on a tidal flat of the Seto Inland Sea, Japan. Mar Ecol Prog Ser 198:139-155

Magni P, Montani S, Tada K (2002) Semidiurnal dynamics of salinity, nutrients and suspended particulate matter in an estuary in the Seto Inland Sea, Japan, during a spring tide cycle. J Oceanogr 58:389-402

Marshall N, Oviall A, Skauen DM (1971) Productivity of the benthic microflora of shoal estuarine environments in southern New England. Int Rev Gesamt Hydrobiol 56:947-956

Middelburg JJ, Barranguet C, Boschker HTS, Herman P, Moens T, Heip CHR (2000) The fate of intertidal microphytobenthos carbon: an in situ ${ }^{13} \mathrm{C}$-labelling study. Limnol Oceanogr 45:1224-1234

Montagna P, Coull B, Herring T, Dudley B (1983) The relationship between abundances of meiofauna and their suspected microbial food (diatoms and bacteria). Estuar Coast Shelf Sci 17:381-394

Montagnes DJS, Berges JA, Harrison PJ, Taylor FJR (1994) Estimating carbon, nitrogen, protein, and chl a from volume in marine phytoplankton. Limnol Oceanogr 39: $1044-1060$

Montani S, Magni P, Shimamoto M, Abe N, Okutani K (1998) The effect of a tidal cycle on the dynamics of nutrients in a tidal estuary in the Seto Inland Sea, Japan. J Oceanogr 54: 65-76

Parsons TR, Strickland JDH (1959) Proximate analysis of marine standing crops. Nature 184:2038-2039

Parsons TR, Maita Y, Lalli CM (1984) A manual of chemical and biological methods for seawater analysis. Pergamon Press, Oxford

Peletier H (1996) Long-term changes in intertidal estuarine diatom assemblages related to reduced input of organic waste. Mar Ecol Prog Ser 137:265-271

Perry MJ (1976) Phosphate utilization by an oceanic diatom in 
phosphorus-limited chemostat culture and in the oligotrophic waters of the central North Pacific. Limnol Oceanogr 21:88-107

Pinckney J, Zingmark RG (1991) Effect of tidal stage and sun angles on intertidal benthic microalgal productivity. Mar Ecol Prog Ser 76:81-89

Pinckney J, Zingmark RG (1993) Biomass and production of benthic microalgal communities in estuarine habitats. Estuaries 16:887-897

Rasmussen MB, Henriksen K, Jensen A (1983) Possible causes of temporal fluctuations in primary production of the microphytobenthos in the Danish Wadden Sea. Mar Biol 73:109-114

Redfield AC, Ketchum BH, Richard FA (1963) The influence of organisms on the composition of sea water. In: Hill MN (ed) The sea, Vol 2. Wiley-Liss, New York, p 26-77

Riaux-Gobin C (1985) Long-term changes in microphytobenthos in a Brittany estuary after the 'Amoco Cadiz' oil spill. Mar Ecol Prog Ser 24:51-56

Ryther JH (1956) Photosynthesis in the ocean as a function of light intensity. Limnol Oceanogr 1:61-70

Editorial responsibility: Otto Kinne (Editor),

Oldendorf/Luhe, Germany
Serôdio J, Catarino F (2000) Modelling the primary productivity on intertidal microphytobenthos: time scale of variability and effects of migratory rhythms. Mar Ecol Prog Ser 192:13-20

Smith DJ, Underwood GJC (1998) Exopolimer production by intertidal epipelic diatoms. Limnol Oceanogr 43: 1578-1591

Stevenson RJ (1983) Effects of current and conditions simulating autogenically changing microhabitats on benthic diatom immigration. Ecology 64:1514-1524

Sullivan M, Moncreiff C (1990) Edaphic algae are an important component of salt marsh food-webs: evidence from multiple stable isotopes analysis. Mar Ecol Prog Ser 162: $45-55$

Sundbäck K, Jönsson B (1988) Microphytobenthic productivity and biomass in sublittoral sediments of a stratified bay, southeastern Kattegat. J Exp Mar Biol Ecol 122:63-81

Tada K, Monaka K, Morishita M, Hashimoto T (1997) Standing stocks and production rates of phytoplankton and abundance of bacteria in the Seto Inland Sea, Japan. J Oceanogr 54:285-295

Submitted: February 5, 2002; Accepted: July 18, 2002

Proofs received from author(s): February 13, 2003 